\title{
'The trees do not belong to Chief Maranke but to the Native Reserves Trust': The politics of timber resource exploitation in African reserves, colonial Zimbabwe, 1924-1948
}

\author{
Clement Masakure and Noel Ndumeya*
}

\begin{abstract}
Contextualised within a settler state characterised by racial discrimination and unequal access to natural resources, this article examines the ideological, environmental and economic considerations surrounding the formation of the Native Reserves Trust (NRT) and the role it played in the exploitation of timber resources in the African reserves of Southern Rhodesia (now Zimbabwe). Cognisant of the fact that the colonial state set aside marginal and less productive reserves for the Africans, the paper uses the NRT as a lens to view the process by which the settler society penetrated African reserves and exploited timber resources that were needed for the white-owned enterprises, while at the same time, Africans were barred from exploiting the same resources in European domains. The study further discusses the significance of timber in the African reserves, analyses the role of the NRT in regulating timber exploitation processes and the relations between the state, timber concessionaire companies and the African communities. Lastly, it assesses the extent to which timber exploitation contributed to environmental destruction, and how this prompted a policy shift, leading to the implementation of state-initiated afforestation programmes in these reserves and how these re-shaped state-African relations. On the whole, we note that the exploitation of timber resources in African areas replicated the larger colonial policy that favoured whites at the expense of Africans.
\end{abstract}

Keywords: Native Reserves Trust; African reserves; timber; afforestation; Southern Rhodesia; colonial Zimbabwe; natural resources.

* Clement Masakure is senior lecturer and head of the Department of History at the University of the Free State. He has published widely on the history of Zimbabwe, including African Nurses and Everyday Work in Twentieth-century Zimbabwe (2020), published by Manchester University Press. Noel Ndumeya is lecturer and head of the Department of Historical Studies at the National University of Lesotho. He is also a research fellow with the International Studies Group, University of the Free State. His research field is the environmental history of southern Africa, with an additional interest in land and agricultural history of the same region. The authors would like to thank the two anonymous reviewers and the editors for providing insightful comments that have helped in shaping the final product of this article. Any errors or omissions remain ours.

How to cite this article: C. Masakure and N. Ndumeya, "'The trees do not belong to Chief Maranke but to the Native Reserves Trust': the politics of timber resource exploitation in African reserves, colonial Zimbabwe, 1924-1948”, Historia, 66, 1, May 2021, pp 6187. 


\section{Opsomming}

Binne die konteks van 'n setlaarstaat wat gekenmerk is deur rasse-diskriminasie en ongelyke toegang tot natuurlike hulpbronne, ondersoek hierdie artikel die ideologiese, omgewings- en ekonomiese oorwegings rondom die stigting van die Native Reserves Trust (NRT), en die rol wat dit gespeel het in die benutting van hout-hulpbronne in die swart reservate van Suid-Rhodesië (die hedendaagse Zimbabwe). Gegewe die feit dat die koloniale staat marginale en minder produktiewe reservate vir Afrikane opsy gesit het, gebruik hierdie artikel die NRT as 'n lens om die proses te belig waardeur die settlaarsgemeenskap die swart reservate binnegedring het en hout-hulpbronne benut het vir wit-beheerde bedrywe terwyl, aan die ander kant van die munt, Afrikane verbied was om dieselfde hulpbronne binne die wit gebiede te benut. Die studie bespreek die belangrikheid van hout binne die swart reservate. Dit analiseer die rol van die NRT in die regulering van hout-hulpbronne, en die verhouding tussen die staat, hout-konsessionarisse en die swart gemeenskappe. Laastens oorweeg dit die mate waartoe die benutting van hout-hulpbronne bygedra het tot die vernietiging van die omgewing en hoe dit gelei het tot 'n beleidsverskuiwing, wat die instelling van staatsgedrewe bebossingsprogramme in die reservate tot gevolg gehad het, sowel as die mate waartoe dit die verhouding tussen Afrikane en die staat beïnvloed het. In die geheel wys ons daarop dat die benutting van hout-hulpbronne in swart areas 'n weerspieëling was van die wyer koloniale beleid wat wit ten koste van swart bevoordeel het.

Sleutelwoorde: Native Reserves Trust; swart reservate; hout-benutting; bebossing; Suid-Rhodesië, koloniale Zimbabwe. natuurlike hulpbronne.

\section{Introduction}

This article analyses the nexus between timber resources, the state and African societies in Southern Rhodesia. ${ }^{1}$ It examines the ideological, environmental, and economic considerations surrounding the formation of the Native Reserves Trust (NRT), and its role in regulating and monitoring the activities of white logging companies in the African reserves. It also discusses how timber exploitation contributed to the degradation of this resource, and how this prompted reforestation programmes that began in the 1930s. Furthermore, it analyses how people, individually or collectively, have cooperated with or contested state regulatory mechanisms over access to, control and use of these resources between 1924 and 1948.

1. We have used colonial place names for this article. Current names are in brackets: Southern Rhodesia/Rhodesia (Zimbabwe), Melsetter (Chimanimani), Chipinga (Chipinge), Umtali (Mutare), Maranke (Marange), Salisbury (Harare), Charter (Chikomba), Mozoe (Mazowe), Umtasa (Mutasa), Marandellas (Marondera), Chilimanzi (Chirumhanzu), Selukwe (Shurugwi), Rusapi (Rusape), Mtoko (Mutoko). Furthermore, we use the terms "white(s)" and "African (s)" as the day-to-day usages of the terms by colonial officials. Within the archives 'white(s)' denoted people of European descent and "African(s)" referred to indigenous people. 
Overall, an examination of the politics of timber exploitation through the NRT gives us an opportunity to explore state programmes in African areas and an analysis of the contestations over timber resources opens ways of examining race relations in Southern Rhodesia: that is, both relations amongst whites and relations between whites and Africans. As will be shown in this article, colonial officials turned a blind eye to white logging companies' indiscretions that caused environmental destruction in African areas. When it came to Africans, not only did colonial officials patronise them, but they also made it difficult for Africans to access timber resources.

Still, Africans were not passive victims of the situation as they responded in various ways - ranging from cooperating with colonial officials to contesting state polices. For example, as exemplified by Chief Maranke, without colonial officials' consent they asserted their authority over timber resources and sold timber to white logging companies. Moreover, even when the colonial officials imposed restrictions on African wood-vending enterprises (thus protecting white wood vendors from competition) Africans continued their wood vending activities. They cooperated when it came to the afforestation programmes and establishing timber plots, but the harvesting of timber was contested as they harvested timber from afforestation plots without seeking permission from colonial officials. In other words, exploitation of timber resources in African areas replicated the larger colonial policy that favoured whites at the expense of Africans and at the same time, in their subordinate position, Africans were important historical actors who cooperated in implementing some projects and contested unfair access to resources.

Throughout southern Africa, access to forest resources has been significant in shaping various communities' livelihoods. This comes out clearly from the works of scholars who explore the struggles over ownership and use of forest resources. The historian Jacob Tropp, for example, examined how, in the process of transforming African reserves into labour reservoirs, colonial authorities restructured Africans' relationship with and access to forest resources and reserved them for the white settler economy - just as they had done with other critical resources such as land and water. ${ }^{2}$ In a related environmental study, historian Karen Brown argued that colonial officials often apportioned blame on Africans, accusing them of deforestation and erosion of the arable land, using this as an alibi for colonial appropriation of Africans' land and its natural resources. ${ }^{3}$ This placed new constraints on local Africans in accessing forest resources and in the process, created protracted contestations between the state and Africans. ${ }^{4}$ Other scholars reveal the intricacies between state, trees and agriculture, especially the authorities' attack on traditional agricultural practices as "wasteful", with the longer-term aim of creating permanent African settlements. ${ }^{5}$ The

2. J. Tropp, Natures of Colonial Change: Environmental Relations in the Making of Transkei (Ohio University Press, Athens: OH, 2006).

3. K. Brown, “Trees, Forests and Communities': Some Historiographical Approaches to Environmental History on Africa", Area, 35, 4, 2003, p 344.

4. See for example, Tropp, Natures of Colonial Change.

5. They also used such ascriptions as pretexts for a developmental agenda often not beneficial to Africans, but suiting their needs. See, for instance, D.K. Davis, Resurrecting 
establishment of permanent African settlements made it easier for colonial authorities to collect taxes and recruit labour as well as for Christian missionaries to gain access to permanently settled African converts. ${ }^{6}$

In the case of Southern Rhodesia, scholars have highlighted various aspects of human-environment interactions, including land and environmental degradation, conservation efforts and human conflicts over access to wildlife resources. The environmental historian, Muchaparara Musemwa, has amply demonstrated how, following colonisation in 1890 and the subsequent rampant exploitation of timber, "... the once verdant landscapes of colonial Zimbabwe were transformed into near waste in the first four decades of colonial occupation". ${ }^{7}$ Further, discussing the environmental implications of long-standing disputes over timber, water, grazing rights and land damage caused by mining operations on white farms along the Gold Belt, he concluded that while white farmers raised concerns about white miners' activities, this was not about "precautionary stewardship" over the environment, but an intra-class "capitalist greed". 8 In addition, historians Tapiwa Madimu, Enocent Msindo and Sandra Swart, in their joint work, moved beyond intra-class struggles and placed the source of resource disputes on the British South Africa Company's bias towards the mining sector at the expense of farmers. ${ }^{9}$ In a related study, environmental historian Vimbai Kwashirai has underscored how the white settler community's ignorance and neglect of environmental concerns resulted in widespread deforestation and soil erosion. ${ }^{10}$ Kwashirai also demonstrated that timber concessionaire companies that felled and processed timber in the Gwai Forest Reserve denied African tenants of the area access to forest products. Similarly, environmental historian Noel Ndumeya has explored how Africans in the eastern highlands of the Chipinga District struggled to gain access to timber and game products in the Chirinda Forest. ${ }^{11}$

the Granary of Rome: Environmental History and French Colonial Expansion in North Africa (Ohio University Press, Athens: OH, 2007).

6. See for example, H. L. Moore and M. Vaughan, Cutting Down Trees: Gender, Nutrition, and Agricultural Change in the Northern Province of Zambia, 1890-1990 (Heinemann, Portsmouth: NH, 1994).

7. M. Musemwa, 'Sic Utere tuo ut Alienam Non Laedas': From Wanton Destruction of Timber Forests to Environmentalism. The Rise of Colonial Environmental and 'sustainability' Practices in Colonial Zimbabwe, 1938-1961', Environment and History, 22, 4, 2016, p 521.

8. M. Musemwa, "Contestations over Resources: Farmer-Miner Dispute in Colonial Zimbabwe, 1903-1939", Environment and History, 15, 1, 2009, pp 79-107.

9. T. Madimu, E. Msindo and S. Swart, "Farmer-Miner Contestations and the British South Africa Company in Colonial Zimbabwe, 1895-1923”, Journal of Southern African Studies, 44, 5, 2018, pp 793-814.

10. See for example, V. Kwashirai, "Dilemmas in Conservationism in Colonial Zimbabwe, 1890-1930", Conservation and Society, 4, 4, 2006, pp 541-561.

11. See V. Kwashirai, "Poverty in the Gwai Forest Reserve, Zimbabwe: 1880-1953", Global Environment, 1, 1, 2008, pp 147-175; and N. Ndumeya, "Conserving Wildlife Resources in Zimbabwe: Reflections on Chirinda Forest, 1920s-1979", Environment and History, 26, 3, 2020, pp 413-442. 
Collectively, what Musemwa, Madimu, Kwashirai and Ndumeya have demonstrated is that contestations over ownership and use of timber resources in Southern Rhodesia were not restricted to "black versus white" communities, but were also an intra-racial problem. However, Musemwa's exposition and the joint work by Madimu, Msindo and Swart concentrated on the struggles over timber between whites and dealt primarily with the areas that were demarcated for white occupation. At the same time, while Ndumeya explored the contestations over Chirinda Forest - initially between Africans and missionaries, and later between Africans and the state - it should be noted that the forest was initially appropriated by white missionaries and farmers, and later it was placed under the direct control of the state. Therefore, Chirinda Forest remained a designated white space. Similarly, Kwashirai's work first focused on white areas, with an emphasis on the environmental impact of gold mining activities among the white community in the Mazoe District, ${ }^{12}$ and then, secondly, on struggles over forest resources in the Gwai Forest Reserve, another forest directly controlled by the state. ${ }^{13}$

We acknowledge that the 1890 colonisation of the land between the Zambezi and Limpopo rivers ushered in race-based division of land, which marginalised the majority of indigenous African societies. Over time, the white settler community confiscated the best land and condemned Africans to the reserves with restricted access to timber and other wildlife resources. ${ }^{14}$ Colonial capital and society continued penetrating the African reserves in pursuit of timber, game and minerals, and for recreational reasons while Africans were barred from seeking the same, often abundant resources in white domains. In the Melsetter District, for instance, white settlers frequented the Musikavanhu and Mutema Reserves, prospecting for gold and for car and bike racing purposes; and rented the Hot Springs Resort Centre located in the Muwusha Reserve, thereby denying Africans residing in this drought-prone area the right to utilise this natural resource. This white settler marginalisation of, and encroachment into African reserves, sowed the seeds of conflict with local Africans. ${ }^{15}$ The then Native Commissioner (NC) for the Melsetter District, Piet Nielson, believed strongly that it was unfair for whites to benefit from resources found in the African reserves and pointed out that Europeans were denying Africans access to resources found in white-owned areas. Accordingly, he wrote several letters to the Chief Native Commissioner (CNC), requesting that whites should not be allowed to continue the exploitation of resources in the African reserves. His plea was in vain. ${ }^{16}$

12. Kwashirai, "Dilemmas in Conservationism in Colonial Zimbabwe”, pp 541-561.

13. Kwashirai, "Poverty in the Gwai Forest Reserve, pp 147-175

14. For historical accounts on land expropriation and the establishment of African reserves see H. Moyana, The Political Economy of Land in Zimbabwe (Mambo , Gweru, 1984); and R. Palmer, Land and Racial Domination in Rhodesia (Heinemann, London, 1977).

15. C. Mabulala, "The Native Affairs Department in Melsetter District: The Administration of L.C. Meredith, 1895-1909 and P. Nielson, 1926-1936", BA Honours, University of Zimbabwe, 1995, p 33.

16. Mabulala, "The Native Affairs Department in Melsetter District", pp 31-34. 
Our study expands these existing studies by covering significant episodes in colonial Zimbabwean environmental history. The 1920s are striking in that following an unprecedented destruction of timber, ${ }^{17}$ the government appointed the first forest officer, J.S. Henkel, in 1920, to head the Forestry Department and manage all the country's forests. ${ }^{18}$ In Zambia, too, the government set up the Forestry Department in 1929, while similarly, the 1920s and 1930s have been described as the conservation era for Tanzania. ${ }^{19}$ Furthermore, the study covers the 1930 s, which were noteworthy in that following the onset of the Great Depression in 1929, both black and white communities diversified their livelihood activities by increasingly resorting to the exploitation of timber. In addition, while providing insight into timber exploitation in the African reserves, this study also explores the role of the state and contestations between white and African communities by analysing the nature of struggles over timber resources between the state, Africans and white timber traders. Then, from the 1930s onwards, it extends its view to encompass the afforestation measures that the state adopted in an effort to augment depleting timber resources in the African reserves.

We begin our study in 1924, when the government formed the NRT. ${ }^{20}$ The post1923 era saw a new phase of rural development that economic historian E. Kushinga Makombe identified as "progress by persuasion". ${ }^{21}$ This era lasted till the late 1940s when the government shifted its policy from "progress by persuasion" to "progress by compulsion". ${ }^{2}$ In line with this shift, the government passed the Native Development Fund Act in 1948. ${ }^{23}$ The Act came into force on 1 April 1949, under which the Native Development Fund Trust was formed.24 This fund began financing community programmes hitherto financed by the NRT. ${ }^{25}$ Thus, we end in 1948 not only because of the passing of the Native Development Fund Act in 1948, but also because the period after 1948 ushered in a new era in government policy towards rural development that was anchored in the use of state coercion.

We situate this article within the literature discussed above. Then, using archival material on the NRT Fund, we contribute to the debates on the contestations over access to timber between the state, Africans and white timber traders in the

17. Musemwa, "From Wanton Destruction of Timber Forests to Environmentalism".

18. Kwashirai, "Poverty in the Gwai Forest Reserve", p 159.

19. Brown, "Trees, Forests and Communities", p 346.

20. See C. Masakure, "The Native Reserves Trust Fund and Rural Development in African Areas c 1924-1948", Unpublished MA thesis, University of Zimbabwe, 2004, p 4.

21. E.K. Makombe, "Developing Rural Africa: Rural Development Discourse in Colonial Zimbabwe, 1944-1971", in J. Hodge, G. Hodl and M. Kopf (eds), Developing Africa: Concepts and Practices in Twentieth-century Colonialism (Manchester University Press, Manchester, 2014) pp 155-178.

22. Makombe, "Developing Rural Africa”, pp 155-178.

23. Masakure, "The Native Reserves Trust Fund", p 4.

24. G.C. Passmore, The National Policy of Community Development with Special Reference to Local Government in the African Rural Areas (University of Rhodesia, Salisbury, 1972), p 40.

25. Masakure, “The Native Reserves Trust Fund”, p 4. 
African reserves, a topic which has received less scholarly attention. Thus, the article begins by tracing the circumstances leading to the formation of the NRT and outlines its mandate. The second section raises the question of the ownership of timber in the reserves and, in the process, analyses the supervisory activities of the NRT in the exploitation of timber. The third section highlights the afforestation activities that the NRT implemented in the reserves from the 1930s, which were prompted by the environmental degradation that had befallen the African reserves. The afforestation programme was intertwined with the early efforts at centralising African reserves.

\section{The timber resource and formation of the NRT}

Timber remains an indispensable resource for African communities and, in particular, residents of the countryside. Throughout the colonial period, the majority of Africans residing in the reserves relied on timber for constructing houses, livestock kraals, fencing and fuel-wood. Further, the communities used timber of various sizes to manufacture a diverse range of implements such as axe and hoe handles, sledges, and the mortars and pestles used in producing, processing and transporting agricultural goods. Other communities utilised forest lands for livestock grazing, hunting, harvesting of herbs and fruits and for carrying out cultural and religious activities such as rain making ceremonies. Colonial restrictions on forest use represented varying constraints on these and other practices, thereby sowing the seeds of contestation over ownership and use of these resources. ${ }^{26}$

Similarly, the exploitation of indigenous timber was a critical economic activity for white settler society in Southern Rhodesia. This was particularly so during the period prior to the establishment of large-scale commercial timber plantations that began in the 1950s. ${ }^{27}$ This explains what Musemwa has described as the "wanton destruction" of indigenous timber resources during the first four decades of the twentieth century in Southern Rhodesia. ${ }^{28}$ Timber was essential for the construction industry; for making mine props, fencing, fuelwood and for furniture-making. Teak wood, in particular, was used primarily for making railways sleepers; most of which were exported to South Africa. ${ }^{29}$ Unsurprisingly, a number of South African timber logging companies were active in the timber business in Southern Rhodesia, among them Baerecke and Kleugden, a company that exploited timber along the BulawayoVictoria Falls highway. ${ }^{30}$

26. See Ndumeya, "Conserving Wildlife Resources in Zimbabwe".

27. See N. Ndumeya, "Acquisition, Ownership and Use of Natural Resources in South Eastern Zimbabwe, 1929-1969", PhD thesis, University of the Free State, 2015, chapter 3.

28. Musemwa, "From Wanton Destruction of Timber Forests to Environmentalism", pp 521-559.

29. Kwashirai, "Poverty in the Gwai Forest Reserve”, p 158.

30. E. Mapedza, "Forestry Policy in Colonial and Postcolonial Zimbabwe: Continuity and Change", Journal of Historical Geography, 33, 2007, p 841. 
While the exploitation of natural resources by white settlers in African reserves benefited the settler community, the formation of the NRT should be understood, firstly, in the context of the ideology prevailing within the Native Affairs Department (NAD). ${ }^{31}$ The ideology - which scholars Jocelyn Alexander, JoAnn McGregor and Terence Ranger call the "secular version of Christian improvement ideology" in their work on Matabeleland (where the first reserves of Gwaai and Shangaan were established) - placed emphasis on state intervention in African peasant production, stock management and the general management of resources. ${ }^{32}$ In other parts of southern Africa, efforts had meanwhile begun to improve African areas by the time under discussion. ${ }^{33}$ The ideas and practices of developing African areas, as Joseph Hodge and Gerald Hodl have pointed out, "stretches back to the mission civilasatrice and constructive imperialism doctrines of the late nineteenth century..."34

A version of the secular Christian improvement ideology had taken root in Southern Rhodesia within the NAD by 1923. Illustrating the foundations of so-called "native policy" in Southern Rhodesia, M.C. Steele has shown that both the Rhodesia Party leaders, H.U. Moffatt and C. Coghlan, believed that Africans had the potential to rise, "albeit slowly, in the scale of civilisation". ${ }^{35}$ This philosophy, though not shared by many whites, influenced the way in which Native Commissioners (NCs) and officials in the NAD administered the African reserves. These officials felt it was their duty to "advance" and "improve" the welfare of Africans in the reserves. Therefore, upon the formation of the NRT, the government passed Notice No. 463 of August 1924, which stipulated that any money, other than taxation, accruing from the exploitation of resources by non-Africans in the reserves be used specifically for the development of these reserves. Besides setting aside funds that would be invested in the development of African areas, the success of such intervention programmes also depended on the cooperation of Africans. Makombe noted that from the 1920s into the early 1940s, state intervention policy in African reserves was anchored in persuading Africans to cooperate in implementing various development programmes. However, from the mid-

31. The Native Affairs Department was the administrative organ of the state responsible for African affairs in the African reserves. It was manned by the Assistant Native Commissioner (ANC) who reported to the District Native Commissioner (DNC) who in turn reported to the Chief Native Commissioner (CNC) in the country's capital city, Salisbury (now Harare).

32. J. Alexander, J. McGregor and T. Ranger, Violence and Memory: One Hundred Years in the "Dark Forests" of Matabeleland (Weaver Press, Harare, 2000), p 69.

33. See for example, K.B. Showers, Imperial Gullies: Soil Erosion and Conservation in Lesotho (Ohio University Press, Athens: OH, 2005); N.J. Jacobs, Environment, Power and Injustice: A South African History (Cambridge University Press, New York, 2003); and W.O. Mulwafu, Conservation Song: A History of Peasant-State Relations and the Environment in Malawi, 1860-2000 (White Horse Press, Cambridge, 2011).

34. J. Hodge and G. Hodl, "Introduction" in Hodge, Hodl and Kopf (eds), Developing Africa, p 2.

35. M.C. Steele, "The Foundations of Native Policy: Southern Rhodesia, 1923-1933, PhD thesis, Simon Fraser University, 1972, p 534. 
1940s onwards, persuasion gave way to coercion and the state began forcing Africans to comply with development programmes. ${ }^{36}$

According to Hodge and Hodl, the concept of development as an international practice was based on the ideology of "trusteeship". ${ }^{37}$ In other words, those who were considered to possess knowledge and those who understood the goals that guided developmental interventions were “... empowered to operate as trustees for humanity...".38 It must be appreciated that the doctrine of trusteeship was central in the ideological foundation of European colonial empires and in the 1920s, this principle was growing in importance. ${ }^{39}$ Hodge and Hodl note that while by this time, "What the ideology of trusteeship meant in practice remained vague and unclear",40 there was, nonetheless, “... increasing pressure on colonial authorities in the 1920s to show that trusteeship, however defined, was being taken seriously". ${ }^{41}$ Pursuant to this, government authorities in Southern Rhodesia set up a board of trustees, composed initially of several well-respected members of the Southern Rhodesian settler community, namely Sir Herbert Taylor, Major Stanley Nettleship Gower Jackson and Sir James Gordon McDonald. Their role was to control funds accrued by the NRT. In the spirit of benevolent paternalism, the NRT administered funds on behalf of the Africans, and as "fatherly figures", officials of the NAD decided on how to use this money. Thus, in 1928, the NC for Umtali emphasised that if properly managed, wood royalties could contribute significantly towards revenue for the development of the reserves: to meet the construction and maintenance of among others, boreholes, roads, bridges, dams and dip tanks. ${ }^{42}$

Secondly, paternalism was again embedded in the prevailing socio-political and economic environment. The end of the British South Africa Company rule and the attainment of responsible government in 1923, meant that power went into settler hands, following which a more segregationist movement came rapidly to the fore in the settler community. As Robin Palmer noted, to prop up white agriculture, the settler government that took over in 1923 capitalised white agriculture and increased investment in areas such as roads and maintenance of infrastructure in white areas. ${ }^{43}$ Closely related to this was the need to avail more land to settlers. Hereafter, authorities

36. Makombe, "Developing Rural Africa", pp 155-178. Makombe identified a number of factors for this change. These include the development of modern manufacturing sector as well as the boom in the export of primary products which compelled the government to rethink its rural development policy.

37. Hodge and Hodl, "Introduction", p 5.

38. Hodge and Hodl, "Introduction", p 5.

39. Hodge and Hodl, "Introduction", p 8.

40. Hodge and Hodl, "Introduction", p 9.

41. Hodge and Hodl, "Introduction", p 9.

42. National Archives of Zimbabwe (hereafter NAZ), S235/358/360, NC Umtali to the CNC, 5 April 1928.

43. R. Palmer, "Agricultural History of Rhodesia", in R. Palmer and N. Parsons (eds), The Roots of Rural Poverty in Central and Southern Africa (University of California Press, Berkeley and Los Angeles,1977), p 236. 
anticipated to push more Africans from the white-owned areas into the reserves. Therefore, government was pressurised to adopt measures designed to improve the carrying capacity of existing African reserves. This was critical, firstly, in light of the population movements that were envisaged under the Land Apportionment Act of 1930, and; secondly, in order to avoid, as far as possible, the necessity for acquisition of more land from white designated areas. ${ }^{44}$

The appointment of Emory D. Alvord as the instructor for Native Agriculture in 1926 was a landmark development in the improvement of African agriculture generally and afforestation initiatives in particular. ${ }^{45}$ Though he was appointed in 1926, concerns about deforestation in African reserves had already become noteworthy by the early 1920s. While Africans were largely blamed for degrading their environments, the mining sector was the dominant culprit, having contributed to an unprecedented scale of deforestation for mining-related construction activities. ${ }^{46}$ Though miners' legal rights ensured them free access to wood and other resources along the Gold Belt, mine contractors often chose to cut down trees in African reserves, where they could easily avoid tariffs.

Consequently, by the onset of the 1920s, NCs in mining districts were complaining of "utter denudation of timber", which they were powerless to control. ${ }^{47}$ While the NC for Inyati expressed similar sentiments about deforestation in the African reserves, he exonerated Africans from his district, writing, "Little or no timber is destroyed by natives in comparison with that felled for mining, the felling of which is gradually depleting miles of country". ${ }^{48}$ Fittingly, upon its formation in 1924, the NRT employed a forest officer, the first of whom was J.S. Wilkins, who served in this capacity from 1924 to $1935 .{ }^{49}$ The officer's primary role was to supervise timber logging in the African reserves and to preserve and improve indigenous timber resources. He later played a significant role in the rural afforestation programmes, which began in the early 1930s.

While it was clear that the mining sector contributed hugely to the deforestation in African reserves, most colonial authorities laid the blame squarely on Africans. They asserted, among other reasons, that the practice of shifting cultivation and the harvesting of forest produce was harmful to forest ecologies. For instance, when the government hired a South African forest expert, James Sim, to investigate the commercial potential of forest resources in Southern Rhodesia, he reported that:

44. Palmer, Land and Racial Domination in Rhodesia, p 202.

45. E. Punt, "The Development of African Agriculture in Southern Rhodesia with Particular Reference to the Interwar Years", MA thesis, University of Natal, 1979, pp 69-89.

46. Musemwa, "From Wanton Destruction of Timber Forests to Environmentalism", p 532.

47. See J. McGregor, "Conservation, Control and Ecological Change: The Politics and Ecology of Colonial Conservation in Shurugwi, Zimbabwe", Environment and History, 1, 3, 1998, p 258.

48. N.C. Inyati, quoted in V. Kwashirai, "Shifting Cultivation: Discourse in Deforestation and Conservation, 1900-1915”, Economic History Seminar Paper, 15 September 2000, p 8.

49. Masakure, "The Native Reserves Trust Fund", p 45. 
In all forest countries inhabited by uncivilised tribes, destruction of forests is a characteristic feature. No value is placed on trees or timber except such as contributes to their hand to mouth existence. In making gardens or lands, big trees are annually destroyed.50

Some colonial officials were critical of the system of shifting cultivation, which was practised commonly, not only among the Shona of Zimbabwe, but throughout indigenous communities of central Africa. Referred to as citemene among the Bemba of Northern Zambia, colonial authorities insisted that this was a wasteful practice, for it involved non-permanency, and constant cutting and burning of trees. However, revisionist scholars have since challenged this narrative. Writing about citemene in 1994, historians Henrietta Moore and Meghan Vaughan argue:

There is a tendency among non-specialist observers to view any system that involved the burning of trees and eventual abandonment of fields as in some sense wasteful ... this was a system well adapted to local environmental conditions as well as being flexible and responsive to change. 51

Critics gave little consideration to the fact that shifting cultivation, as practised among the African communities, promoted soil fertility, leading to higher agricultural output. Once exhausted, the shift to another portion allowed the previous field to regain fertility and for forest re-growth. Therefore, blind criticism of the shifting cultivation indicated either a clear lack of appreciation of what are now termed indigenous knowledge systems, or was simply an alibi to justify colonial intervention in indigenous land use practices. The next section examines questions about the ownership of trees in the African reserves, the relations between timber logging companies and the NRT, and how the NRT supervised the exploitation of timber from these reserves.

\section{Exploiting timber resources in the reserves}

A reckless exploitation of timber, primarily driven by the needs of an expanding mining and railway sector, remained a key feature of the three decades that followed the formation of the Southern Rhodesian state in 1890. This wanton exploitation of timber resulted from a lack of a clear forestry policy, and the fact that up to 1920, soil and forestry management was the responsibility of a single irrigation official, a post occupied by W.M. Watt from 1910 to $1920 .{ }^{52}$ Government finally appointed James Henkel as the first forest officer for Southern Rhodesia in 1920. The key task of this newly appointed official was to manage all the territory's forests and forest resources, which involved regulating timber-logging operations by licensed concessionaire companies and controlling human-induced environmental hazards such as veld fires and the cultivation of slopes and along river valleys. There was indeed an urgent need, considering the amount of forest destruction that had already taken place prior to

50. J. Sim, quoted in Kwashirai, "Shifting Cultivation: Discourse in Deforestation and Conservation", p 2.

51. Moore and Vaughan, Cutting down Trees, p 26.

52. Kwashirai, "Poverty in the Gwai Forest Reserve", pp 158-59. 
Henkel's appointment, for environmental protection regulations that would become the basis for arresting the deteriorating ecological conditions in the countryside.

Meanwhile, a persistent controversy surrounding the exploitation of timber in the African reserves was that of its ownership. This was a contested terrain particularly between the state, African communities and the timber logging companies. This comes out clearly in a 1929 exchange involving the NC for Umtali and Chief Maranke of the Maranke Reserve and Messrs. Higgins and Hatcher, who operated a farm near Odzi, along the Salisbury-Umtali Railway line. In their eagerness to diversify into sawmilling, Higgins and Hatcher applied for a licence in 1928 to cut timber from the nearby, "undoubtedly well wooded" Maranke Reserve - well known for its abundance of "valuable timber trees". ${ }^{53}$ In 1924, the NC listed 13 such "valuable species", five of which were Ironwood, Bloodwood, Mahogany, Ebony and Mupani (Mopane). ${ }^{54}$ In Higgins and Hatcher's application, one can discern controversies surrounding ownership of timber in the African reserves:

\begin{abstract}
We apply to cut timber in Maranke Reserve. We have not seen the chief personally but he has sent a message to us through Alias Dick, who has worked for the writer for the past 10 years that he, (the chief), will be pleased if you will agree. We offer to supply the old chief with a practically new scotch cart built by Messrs. G and Company of Salisbury and has only 6 weeks work and cost $£ 55$... We suggest we should give it another coat of red paint to paint out our name and put the chief's name on the same...55
\end{abstract}

It is clear here that Higgins and Hatcher were convinced that timber in the Maranke Reserve was under the jurisdiction of the chief, whose authority had to be sought before accessing it. This was indeed in accordance with African customary norms. In a follow-up communique, Higgins and Hatcher reinforced their position, assuring the NC that "We might mention that Chief Maranke has no objection". ${ }^{56}$ Nevertheless, the NC vehemently dismissed this standpoint. Responding to Higgins and Hatcher's first application, he said, in a statement that gives rise to the title of this article:

... I regret to find that I am unable to recommend it to the Chief Native Commissioner as it stands. The trees do not belong to Chief Maranke but to the Natives Reserves Trust. Any payment will therefore have to be made into that fund. .5

53. NAZ, S235/358/360, correspondence, NC Umtali to CNC, 24 April 1928.

54. NAZ, S235/358/360, correspondence, NC Umtali to CNC, 24 April 1928.

55. NAZ, S235/358/360, correspondence, Higgins \& Hatcher to NC Umtali, 4 February 1928.

56. NAZ, S235/358/360, correspondence, Higgins \& Hatcher to NC Umtali, 22 February 1928.

57. NAZ, S235/358/360, correspondence, NC Umtali to Higgins \& Hatcher, 11 February 1928. Emphasis ours. 
Meanwhile, without consulting African chiefs, the NRT, NCs and assistant NCs, signed various agreements that allowed several concessionaires to log timber in the African reserves. Among the companies that were granted these licences were the Native Timber Concession, Higgins and Hatcher, Fingo Gold Mining Syndicate, Ralstein and Krinkler, and Baerecke and Kleugden. The NCs were also responsible for checking the exploitation of timber in their respective areas on behalf of the NRT, and for the benefit of the Africans. While a significant proportion of these agreements were based on timber, others concerned firewood. 58

That aside, from the mid-1920s, the government promulgated a number of measures on environmental conservation. The Native Reserves Forest Produce Act (NRFPA) of 1928 was the first piece of conservation legislation. It provided for state regulation of natural resource use, specifically within African reserves. The NRFPA banned the cutting of trees for any purpose other than the "direct fulfilment of subsistence needs"; it also protected selected valuable species against felling for any purpose whatsoever; and it introduced a NC-controlled application procedure to regulate timber concessions. ${ }^{59}$ This Act was revised in 1936 and became the Forest and Herbage Act of 1936 which targeted the conservation of indigenous timber. ${ }^{60}$ The Forest and Herbage Act permitted Africans to exploit forest products such as honey, wild fruits, broom and thatch grass, provided this was for domestic use only. This meant that all commercial trading of forestry products was under state regulation. ${ }^{61}$ Geographer JoAnn McGregor has pointed out that if the timing and context of much of the legislation reflected the ideas of a regional scientific culture, the Southern Rhodesian segregationist politics and interests of different segments of the Rhodesian society could explain its implementation. ${ }^{62}$

Conservation intervention measures were not immediately effective. According to Ian Phimister, although by the 1930s the government had promulgated several environmental conservation regulations, these were largely ineffective due to enforcement laxities. ${ }^{63}$ One explanation for this is that these measures were enacted just prior to the outbreak of the Great Depression. The depression compelled both white settlers and African communities to turn to environmental resources for survival, with the chief activities being wood vending and gold panning. ${ }^{64}$ This had a deleterious effect on the environment.

58. NAZ, S2217/1, Native Reserves Trust (hereafter NRT), Forest Officers Reports, Annual Report, Forest Officer, 1935.

59. McGregor, “Conservation, Control and Ecological Change”, p 259.

60. NAZ, S989, Natural Resources Act, 1941.

61. Mapedza, "Forestry Policy in Colonial and Postcolonial Zimbabwe”, p 842.

62. McGregor, "Conservation, Control and Ecological Change”, p 259.

63. I. Phimister, "Discourse and the Discipline of Historical Context: Conservationism and Ideas about Development in Southern Rhodesia, 1930-1950", Journal of Southern African Studies 12, 2 1986, pp 263-275.

64. I. Phimister, An Economic and Social History of Zimbabwe: Capital Accumulation and Class Struggle, 1890-1948 (Longman, London, 1988), pp 184-185. 
Nonetheless, colonial officials realised the need to monitor the timber-cutting activities of both the timber logging companies and Africans resident in the reserves. As in South Africa, this had been a cause of conflict between state officials and Africans owing to the communal ownership of land and wildlife resources in African communities. In the former Transkei region of the Eastern Cape, the government enlisted local chiefs and headmen in forestry patrol activities, but this proved ineffective, because these traditional leaders shaped their environmental authority as they saw fit, much to the ire of colonial officials.65 "In many cases", writes Tropp, "African authorities wilfully opposed or ignored forest laws in order to shield local residence livelihoods from governmental influences, or manipulated their role in forest control to suit their own political and personal pursuits". ${ }^{66}$ Similar contestations occurred over the ownership and use of the forest resources in eastern Zimbabwe, where Chief Mapungwana, for instance, contested the exclusion of Africans from accessing forest resources in the Chirinda Forest. ${ }^{67}$

The struggles over the exploitation of timber resources in the African reserves also provide a window to view race relations in Southern Rhodesia. The conservation laws the state had promulgated by the 1930s were applied more rigidly to Africans than to Europeans. In contrast to the leniency shown to settlers, the NRFPA was used to levy tariffs on Africans selling firewood. Colonial authorities argued, unashamedly, that Africans' "flagrant profiteering" constituted "unfair competition" for European traders. Blanket restrictions on peasant farmers cutting down trees were also included under the NRFPA but these controls remained problematic because they criminalised every African household. However, the NAD had neither capacity nor the strong inclination to challenge the assertions that Africans were profiteering from wood vending and unfairly competing with European wood vendors. ${ }^{6}$

Poor pricing and sheer wastefulness of timber were rampant, particularly before 1935. This emanated partly from the fact that prices charged on timber logging were mutually agreed upon between the respective NCs, acting on behalf of the NRT, and the logging companies. Thus, timber companies exploiting teak in parts of Matabeleland arranged with NCs to pay royalties not on the basis of timber felled, but on the timber that had actually been exported from the sawmill. Consequently, timber loggers felled numerous trees only to abandon some of them in the forests. The waste was thus considerable. It was reported in 1935 that "from 30-35 per cent of the timber actually felled and brought to the mill is exported by rail ... the remaining 65-70 per cent cut by the companies was left in the field of exploitation". 69

65. Tropp, Natures of Colonial Change, p 44.

66. Tropp, Natures of Colonial Change, $\mathrm{p} 44$.

67. N. Ndumeya, "Nature, Conservation and Conflict in Eastern Zimbabwe: The Case of Chirinda Forest, 1980-2000", Journal of Southern African Studies, 45, 2, 2019, pp 253271.

68. McGregor, “Conservation, Control and Ecological Change”, p 260.

69. NAZ, S2217/1, NRT, Forest Officers' Reports, Forest Officer, Report No. 15, 1935. 
However, these wasteful practices were not always deliberate. The distance from sites of timber felling to the sawmill also affected the quality of timber. For instance, in the Kalahari Sands area of Matabeleland, teak was transported for over 16 miles to the sawmill, while the Zambezi Saw Mills transported teak some 100 miles to the saw mill. ${ }^{70}$ Similarly, Higgins and Hatcher complained that they transported timber for over 30 miles from the Maranke Reserve to their Odzi sawmill which added greatly to the cost. ${ }^{71}$ These factors contributed to the wastefulness by some companies, including the South African owned Baerecke and Kleugden, which operated along the Bulawayo-Victoria Falls railway line. ${ }^{72}$

Forest officers were concerned about the wastage. In an effort to improve the recovery of timber to between 50 and 60 per cent, the Forestry Department devised a new pricing system in 1935. The department proclaimed: " ... the disposal of timber should be by [the] standing of the tree", as was the practice "all over the world". ${ }^{73}$ This new system effected the sale of timber "on the lock, stock and barrel basis" and timber was, thereafter, sold at a flat rate of $11 / 2 \mathrm{~d}$ per cubic foot. ${ }^{74}$ This policy implied that the companies now had to pay for trees felled and not sawn. Officials anticipated that besides curbing the wastage, the pricing policy would increase the funds accruing to the NRT.

However, the policy outlined above did not prove wholly effective. There were conflicting interests between the need to sustain timber reserves and to generate income. Some NCs argued that there was a trade-off between conservation and development with most preferring the latter. Therefore, some turned deaf ears to criticism about the destruction caused by logging companies because they feared the likelihood of losing a sizable revenue from timber royalties, which funded development in the reserves. Others waived tariffs on the grounds that free timber furthered development and brought sectors such as the mining industry to the reserves by providing jobs and opening up what were formerly remote areas. Hence, some officials allowed logging companies to pay paltry royalties, while others waived them. ${ }^{75}$ The comment by the NC for Umtali, following a negotiated royalty between the assistant native commissioner (ANC) for Maranke and Higgins \& Hatchers' concession is illustrative:

The price charged is quite insufficient for the valuable timber ... being cut. The grantees are paying $2 \mathrm{~d}$ for a log of Muonya wood which they sell at 5/- to $£ 1$. Muwanga wood is as valuable and they are getting it at 15/- a cord. ${ }^{76}$

70. NAZ, S2217/1, NRT, Forest Officers Reports, Forest Officer, Report No. 15, 1935.

71. NAZ, S235/358/360, CNC, Letter to the NC Umtali, 30 October 1930.

72. Mapedza, "Forestry Policy in Colonial and Postcolonial Zimbabwe", p 841.

73. NAZ, 2217/1, NRT, Forest Officer, Report No. 15, 1935. This meant that the companies had now to pay for trees felled and not sawn.

74. NAZ, 2217/1, NRT, Forest Officers Reports, Forest Officer Report No. 151935.

75. McGregor, “Conservation, Control and Ecological Change”, p 260.

76. NAZ, S235/358/360, CNC, NC Umtali to the CNC, 29 July 1930. 
Consequently, deforestation remained prevalent because in these instances conservation took second place to the colonial officials and miners' economic interests, and the developmental project of colonialism.

The pricing of timber also created animosity between colonial officials and timber loggers. For instance, in 1928, the CNC complained that the price for a cubic foot, a royalty of 5/- per cord for small timber, was too low. ${ }^{77}$ A stacked cord occupied a volume of 128 cubic feet.78 The actual cubic content of logs, however, did not approach this figure considering that cubic content decreases as the number of logs increases. Moreover, the shape of logs was an important factor in determining the content of the cord. The forest officer noted that an average size for a cord of wood in Southern Rhodesia was 70 solid cubic feet, though 52 cubic feet was the norm. ${ }^{79}$ Thus, Higgins and Hatcher had everything to gain because they also used bent poles and logs of Ironwood (Muwanga) for felloes. ${ }^{80}$ Therefore, they could extract a true cord of wood, which contained 60 cubic feet of timber. ${ }^{81}$ This meant a royalty of only $1 \mathrm{~d}$ per cubic foot, which was far too low and thus Higgins and Hatcher made a huge profit, while prejudicing the NRT of the much-needed revenue.

The wood vending sector was another area of concern. Both the NRT and the NAD strictly supervised the activities of African wood vendors on the grounds that they caused unfair competition for their European competitors. With the onset of the Great Depression, African vendors were left exposed because the authorities adopted measures designed to cushion Europeans against African competition. For instance, the ANC for Shamva recommended either the cancellation of permits of the seven African vendors who operated in the sub-district, or an increase in their monthly royalty, asserting that the African vendors "were placed in a particularly favourable position, and [could] supply wood at a cost far below the European vendors". 82 These Africans sold an average of two wagonloads of wood each week, making an average gross income of $£ 10$ per month. The ANC was bitter about this and complained that:

... this method of acquiring a living by natives under existing conditions is slothful and a retrogressive step in their development, as they are neither exercised mentally or bodily to any degree to obtain this livelihood. Further, I feel that the competition between [the] European and native is not on an equitable basis [as] ... the economic conditions under which each acquire wood from this land shows. ${ }^{83}$

Arguably, the complaint aired by the ANC above cannot be justified. The African vendors were neither lazy, nor "backward": they were rational and enterprising agents. Often, Africans utilised family labour in wood vending enterprises, just as they did in

77. NAZ, S235/358/360, CNC to the NC Umtali, 6 July 1928.

78. NAZ, S235/358/360, Memorandum by the Forest Officer, 26 August 1929.

79. NAZ, S235/358/360, Memorandum by the Forest Officer, 26 August 1929.

80. Felloes are segments or whole rims of a wooden wheel.

81. NAZ, S235/358/360, Memorandum by the Forest Officer, 26 August 1929.

82. NAZ, S138/61 Assistant NC Shamva to the NC Mazoe, 26 August 1929.

83. NAZ, S138/61, Assistant NC Shamva to the NC Mazoe, 26 August 1929 
their agrarian activities. At the same time, white vendors hired and paid labourers for cutting and transporting wood to the market, and then openly lobbied for state protection against African competitors. Furthermore, the effort invested in wood vending was less than that of wage labour, and African vendors generated more income from wood vending than they would have from wage-based employment. Thus, for instance, the minimum wage rate for Africans working in urban areas from the late 1930 s to the 1940 s was between $26 /-$ and $47 / 8$ per month. ${ }^{84}$ The white farming areas during the same period paid a lower wage.

Racial prejudice against Africans should be understood in the context of the economic challenges affecting the white settler community during the Great Depression of the 1930s. The depression wrought havoc on the Rhodesian economy and impoverished a good number of settlers. Phimister noted that, because of the Great Depression, thousands of commercial farmers went out of production, swelling the ranks of unemployed whites. This resulted in a new phenomenon in the countryside, where penniless settlers were forced off their farms and joined experienced gold prospectors. These settlers, “... wandered from district to district hoping to strike a gold deposit rich enough to turn the economic tide flowing against them". 85 While some turned to gold prospecting, others ventured into wood vending, as the ANC for Shamva confirmed:

The depression in farming existing in this district has necessitated farmers looking to other sources to derive temporary revenue until they right their affairs again, and one of these sources at present is the sale of firewood from lands, which have been stumped and cleared of trees and bushes. ${ }^{86}$

However, some white vendors were unable to withstand African competition. This explains, as will be demonstrated shortly, why there was state intervention against African wood vendors. This took the same form as the promulgation of the Cattle Levy Acts of 1931 and 1934 which imposed a levy on the slaughter of African-owned cattle in order to subsidise export stock almost exclusively owned by white farmers. ${ }^{87}$ Similarly, the state promulgated the Maize Control Acts of 1931 and 1934, which depressed prices paid to Africans who grew maize in order to subsidise the returns received by white farmers. ${ }^{88}$

84. P. Ibbotson, quoted in C. Masakure, “'An Unfulfilled Step': An Examination of the Commission to Investigate the Socio-Economic Conditions of Africans Employed in Urban Areas, 1944", B.A. Honours, Economic History, University of Zimbabwe, May 2001, p 17.

85. Phimister, An Economic and Social History of Zimbabwe, p 173.

86. NAZ, S138/61, CNC, ANC Shamva to the NC Mazoe, 26 August 1929.

87. Phimister, An Economic and Social History of Zimbabwe, p 184.

88. Phimister, An Economic and Social History of Zimbabwe, p 185. See also C.F. Keyter, "Maize Control Act in Southern Rhodesia 1931 to 1940: African Contribution to White Survival", Rhodesia History, 8, 1977, pp 1-30. 
The government intervened to protect white wood vendors against African competition. This intervention happened in three ways. Firstly, it restricted African wood vendors to the African market. Prior to this decision, African vendors could sell their firewood to Europeans and to Africans. Secondly, it fixed the price that African wood vendors could charge. ${ }^{89}$ Contrary to the assertion by the NC for Mazoe that fixing price for African wood vendors levelled the relative position of the European and the African vendors, ${ }^{90}$ it actually reduced the Africans' profit margins and discouraged them from selling wood to make a living, which then expanded the market for white wood vendors. Thirdly, it imposed an annual tax of $£ 5$ on African wood vendors, which was subsequently credited into the NRT Fund. ${ }^{91}$ Thus, it became mandatory for these Africans to contribute to the NRT Fund, contrary to the stipulations of Government Notice of 1923, which stated that funds for the NRT should come from non-Africans who were operating in the reserves. This meant that by the 1940s, Africans were contributing a substantial amount to the NRT Fund, a fact which the trustees clearly acknowledged. ${ }^{92}$

While wood vending regulations were rigidly applied to Africans, they were enforced arbitrarily on white wood vendors. This laxity remained even when the European timber loggers and vendors openly breached various regulations that the state promulgated to control the exploitation of timber in the reserves. For instance, to encourage quick regrowth, it was mandatory to practise 'low felling': in other words, to leave stumps with a slightly sloping surface, and with undamaged bark. ${ }^{93}$ Yet, after an inspection of felling areas in the Lundi Reserve, under the timber concession granted to the company of Ralstein and Krikler, the forest officer observed several breaches of these conditions, the most serious being that trees were cut 10 inches above the ground, which was too high to promote regrowth. ${ }^{94}$ Clearly, for Ralstein and Krikler, the profit motive was much higher than the desire to replenish timber in the African reserves.

In some instances, logging companies observed logging rules selectively. In a 1938 report, the forestry officer praised Higgins and Hatcher, operating in the Maranke Reserve, for conforming to certain logging clauses. The officer was satisfied that the Mukwa (Mubvamaropa) and Pod Mahogany (Mukamba) species had been felled satisfactorily, adding that the height of stumps was as per logging regulations. However, he expressed reservations regarding the fourth clause of the 1926 Act, which prohibited felling of trees within 20 feet of either bank of any stream. Commenting on the Black Thorn (Muguhungu) trees, he said "a fair proportion of this species" had been "felled on ant heaps which fall within 20 feet of either bank of certain streams in the concession area". 95 He was also upset that Higgins and Hatcher had abandoned a

89. NAZ, S138/61, CNC, ANC Shamva to the NC Mazoe, 26 August 1929.

90. NAZ, S138/61, NC Mazoe to CNC, 28 September 1928.

91. NAZ, S138/61, NC Mazoe to CNC, 28 September 1928.

92. NAZ, S2995, NRT, The Report of the Trustees, 1946.

93. NAZ, S2217/2, NRT, Forest Officers' Reports, Forest Officer Report No. 451, 1938.

94. NAZ, S2217/1, NRT, Forest Officers' Reports, Annual Report, 1935.

95. NAZ, S2217/2, NRT, Forest Officers' Reports, Report No. 451, 1938. 
number of trees that they had felled. Finally, the forestry officer was annoyed, after noting several felled Iron Wood (Muwanga) trees, which, from examination, indicated that the trees were unsound and would not have yielded quality timber. ${ }^{96}$

That aside, some unscrupulous companies acquired timber outside the demarcated territories. In 1940, the forest officer for Umtali raised these concerns upon observing a number of the Black Thorn trees that the logger felled outside the concession area in Maranke Reserve. ${ }^{97}$ However, instead of a penalty, the officer let Higgins and Hatcher off the hook with a mere reprimand. Therefore, the colonial supervisors sacrificed the conservation of timber for the profit motive of the concessionaire companies. This implies that timber logging in the African reserves was a clear replication of the colonial racial policy, favouring the economic interests of the white settler community at the expense of environmentalism and that of the African residents of the reserves.

Yet, over the course of this period, Africans and concessionaire companies also found ways of defrauding the NRT to their benefit. Some concessionaire companies secured timber by conniving with Africans. In such cases, the companies circumvented the NRT by buying timber directly from African residents of the reserves. The companies made huge profits by, on one hand, defrauding the NRT while on the other hand paying African timber suppliers low prices. ${ }^{98}$

Moreover, some landowners had logs converted at the concessionaires' sawmills in the reserves at a charge of ten shillings per sawing. ${ }^{99}$ It is highly likely that this system was abused because timber from other parts of the reserve would find its way to sawmills from different landowners. In this way, the companies managed to make a profit at the expense of the NRT, as money was supposed to be paid to the NRT Fund. This meant that Africans lost out because timber was exploited without adequate compensation.

Having discussed the NRT's supervisory activities and the influence of the Great Depression on the environment, the next section focuses on afforestation activities that the NRT administered in African reserves. These were informed, on one hand, by declining timber resources, and on the other, by the need to increase the carrying capacity of these reserves.

96. NAZ, S2217/2, NRT, Forest Officers' Reports, Report No. 451, 1938.

97. NAZ, S2217/2, NRT, Forest Officers' Reports, Report No. 61, 1940.

98. NAZ, S2217/2, NRT, Forest Officers' Reports, Report No. 61, 1940.

99. NAZ, S2217/2, NRT, Forest Officers' Reports, Report No. 61, 1940. 


\section{Afforestation activities in African reserves}

Timber shortages in some of the African reserves had become glaringly obvious by the early 1930s. For instance, by 1933, residents of the Umtasa North Reserve obtained most of their firewood from the hills and transported wood "for some considerable distance", ${ }^{100}$ while their counterparts in the Umtasa South Reserve, "had to travel many miles to obtain ... firewood". ${ }^{101}$ Based on the estimation of two cords per African per annum, the forest officers projected that approximately 2400 cords or 144000 cubic feet of timber was required annually as wood fuel by Africans in the Umtasa North and Umtasa South reserves. ${ }^{102}$ Similarly, the projection for the Zimunya Reserve of the Umtali District was two cords of timber per African per annum, which amounted to approximately 5300 cords or 318000 cubic feet. ${ }^{103}$ No doubt, this was a large amount considering that existing timber reserves were now generally poor. Fearing that in a short space of time the timber shortage would deteriorate further, the forestry officer for Umtali pointed to "... the pressing need for the establishment of rapidly growing trees and the conservation of present supplies of indigenous timber". ${ }^{104}$

There were ecological concerns as well. Forest officers feared that continuous depletion of timber on mountain slopes would result in greater environmental challenges such as worsening soil erosion, promoting river and dam siltation which would lead to poor harvests and food insecurity. Ultimately, the carrying capacities of the various reserves would diminish tremendously, thereby increasing pressure on the government to implement food relief schemes or allocate more land for Africans outside the existing reserves. All this pointed to the need for an afforestation programme. 105

Afforestation activity in African reserves began in the 1920s and only picked up momentum in the 1930s. Using African labour, afforestation progressed in tandem with the centralisation programme, which the state implemented in certain African reserves from the 1930s. ${ }^{106}$ The centralisation programme involved re-planning and laying out African villages. Forest officers worked in tandem with the Department of Native Agriculture in establishing the new villages, setting aside permanent arable, grazing and forest areas and giving rise to model "village lines". This contributed to heightened afforestation activities, as hundreds of community tree plantations were set up for use by various African villages. As a result, in 1935 the instructor for Native Agriculture, E.D. Alvord, who realised that afforestation could play a complementary

100. NAZ, S2217/1, NRT, Forest Officers' Reports, Umtali District, 1933.

101. NAZ, S2217/1, NRT, Forest Officers' Reports, Umtali District, 1933.

102. NAZ, S2217/1, NRT, Forest Officers' Reports, Umtali District, 1933.

103. NAZ, S2217/1, NRT, Forest Officers' Reports, Umtali District, 1933.

104. NAZ, S2217/1, NRT, Forest Officers' Reports, Umtali District, 1933.

105. In the case of former French West Africa, see for instance E. Ndione, P. de Leener, M. Ndiaye, P. Jacolin and J-P Perier, The Future of Community Lands: Human Resources, (Intermediate Technology, London, 1995).

106. See Passmore, The National Policy of Community Development, p 23; and MacGregor, "Conservation, Control and Ecological Change in Shurugwi", pp 261-266. 
role in general agricultural improvement in the African reserves, and who supported the establishment of community tree plantations throughout the deforested areas, ${ }^{107}$ requested the transfer of Wilkins, the forest officer from the NRT, to the Department of Native Agriculture. Alvord argued that,

The establishment of tree plantations in deforested areas and the central regulation with regard to cutting timber, clearing new lands etc. in the timbered areas are so closely linked up with our development work in the Reserves, cultivation of arable lands and grazing lands and the work of agricultural demonstrators, that it is important that such forestry work be placed under the jurisdiction and direction of this office and a defined forestry policy should be included in our scheme for the development of Native Areas and Reserves. ${ }^{108}$

Convinced by Alvord's argument, the government transferred Wilkins from the NRT to the Department of Native Agriculture in 1936.

Nevertheless, sources show that Southern Rhodesia's rural afforestation programmes did not begin with the NRT. Census records indicate that as early as 1904, there were over 137000 Eucalyptus trees in Southern Rhodesia, and of these, the Salisbury District had four plantations of over 1000 trees each. ${ }^{109}$ While these were in the white farming areas, the first recorded African reserves where NCs organised afforestation projects on behalf of the NRT were in Marandellas and Selukwe in 1925. Reporting on progress towards the establishment of Eucalyptus plantations, the NRT said that a large proportion of its 1925 budget "had been expended on the preparation of suitable sites and the purchase of young trees and seed". 110 This had spread to the Mazoe District by 1931, where the local NC reported: "Progress has been made in afforestation schemes and, owing to the shortage of timber, the results should be much appreciated by the Africans in Chiweshe in the course of time."111

In 1930, the NRT claimed that afforestation had made some progress. It reported five plantations of 180000 trees in the Chilimanzi Reserve, 10000 trees in the Zvimba Reserve and substantial plantings in the Gutu and Selukwe Reserves. Further, it mentioned that there was some progress on tree planting in both the Marandellas and Charter Districts. ${ }^{112}$ In the Bikita District, a total of 25 acres were under afforestation. ${ }^{113}$ Each year, the acreage under trees increased. For example, in 1935 alone, 61260 trees were planted and 6810 seedlings distributed. The CNC expressed gratification that tree planting was undertaken on the initiative of the

107. NAZ, S2990/1, NRT, Letter from E.D Alvord to the CNC, 16 November 1935.

108. NAZ, S2990/1, NRT, Letter from E.D. Alvord to the chairman of the Trust, 16 December 1935.

109. A.G. Davis, "Afforestation in the Mazowe Valley", Zambezia, 15, 2, 1988, pp 119-137.

110. NAZ, S235/344, Chief Native Commissioner, Trust Affairs, 1924-1924, Trustees' Report, 1925.

111. The NC Mazowe quoted in Davis, "Afforestation in the Mazowe Valley", pp 122.

112. NAZ, S482/542/39 Prime Minister, Reports of Board of Trustees (NRT), 1930-1947, Trustees' Report, 1930.

113. NAZ, S482/542/39 Prime Minister, Reports of NRT Board, Trustees' Report, 1930. 
Africans in certain poorly-timbered reserves. ${ }^{114}$ In 1941, the NC for Concession sold 326 poles from timber plots to Africans for roofing and oversaw the establishment of two new plantations of $2 \frac{1}{2}$ acres. He wrote. "... good work has been done, and the benefits are now being reaped by natives who are building better huts under the centralisation scheme". ${ }^{115}$

Nevertheless, efforts towards afforestation were initially characterised by trial and error, and debates over which tree varieties to grow. While some, as was the case with the NC for Concession, favoured indigenous tree species, their effort was mostly in vain, due to the lack of adequate extension services in raising indigenous tree species. ${ }^{116}$ The NC for Rusapi, was, from the onset, against the idea of growing indigenous trees because their growth rate was slower compared to that of exotic trees. ${ }^{117}$ As a result, although the propagation of indigenous trees was not ruled out, the NRT gave priority to afforestation driven by exotic species.

The second debate during the afforestation effort centred on whether it should be driven by conifers, eucalyptus or wattle species. While conifers were grown in certain African reserves, they were not widespread because they do not coppice; ${ }^{118}$ implying that when an area of conifers was cut over, it had to be replanted. This contrasted with eucalyptus varieties that coppice freely, in the process saving labour and costs of replanting. Wilkins argued that an urgent need to augment timber supplies in the poorly stocked reserves meant that preference should be given to eucalyptus trees which grew faster than conifers. ${ }^{119}$ Additionally, eucalyptus species were more economical, as they produced more timber per unit of land. Thus, a ten-year-old plantation of harder conifer varieties planted at a site in Marandellas had a volume of approximately 800 cubic feet per acre, whereas a eucalyptus plantation grown under similar conditions produced more than four times that volume in the same period. ${ }^{120}$ Preferring the eucalyptus, the NC for Mtoko wrote:

I hope that the Trustees will agree to gum trees planted in this district. A quick return is essential. To expect them to wait for 15 years for a conifer or indigenous tree to mature is a hopeless case. ${ }^{121}$

This does not mean that conifer species were not grown, but more eucalyptus trees were planted because they grew rapidly. While the eucalyptus species dominated most reserves, the wattle trees were established in parts of the humid eastern districts in the

114. NAZ, S482/542/39 Prime Minister, Reports of NRT Board, Trustees' Report, 1936.

115. NAZ, S2990/4 NRT, NC Concession to the Secretary of the NRT, Report on work, 1941.

116. NAZ, S2990/2, NRT, NC Concession to the Chairman, 28 December 1936.

117. NAZ, S2990/2, NRT, NC Rusapi to the Secretary of the Trust, 14 December 1934.

118. NAZ, S2990/1, NRT, J Wilkins to the Chairman of the Trust, 4 September 1934. Trees that coppice develop shoots from remaining stumps, and normally grow faster than the original tree.

119. NAZ, S2990/1, NRT, J Wilkins to the Chairman of the Trust, 4 September 1934.

120. NAZ, S2990/2, NRT, NC Mtoko to the Secretary of the Trust, 16 December 35.

121. NAZ, S2990/2, NRT, NC Mtoko to the Secretary of the Trust, 16 December 35. 
vast, sparsely populated parts of the Nyamaropa Reserve. ${ }^{122}$ This was to accommodate hundreds of Africans who were to be relocated there from white-owned lands. ${ }^{123}$ The local NC insisted that Africans could not occupy this area until timber plantations had been established, explaining that:

It is the intention to settle a larger native population in this Reserve than there is at the present time. Suitable land to do this is situated at the higher elevations and this land, except for some of the deep - watercourses near the eastern edge is treeless. Timber supplies must be established before settlement can be effected. ${ }^{124}$

Clearly, afforestation activities in the African reserves were meant to improve the carrying capacity of the reserves and create more space for commercial farming activities in the white-owned areas.

Despite the successes, the rural afforestation scheme had its share of challenges. Key among these was the damage done to young plantations by livestock. For instance, cattle browsing and trampling damaged a two-acre wattle plot planted in the 1938-39 rain season in the Nyamaropa Reserve. The forest officer blamed Africans for this, despite the fact that the plot was not fenced: "The prepared strips are situated some distance from the few existing native kraals ... and it would appear that there is sufficient grazing area between the kraals and the strips to satisfy the requirements of livestock". 125

Occasional natural disasters constituted another challenge. In 1947, for example, two one-acre eucalyptus plantations in Bindura failed totally owing to adverse climatic conditions and one of the plantations had to be replanted no less than three times. ${ }^{126}$ In the Mazoe District, locusts devoured plantations while termites attacked gum tree seedlings severely. On visiting this district, the conservator of forests, A.A. Pardy, concluded that drought, lack of fencing and termites were the main drawbacks towards establishing viable plantations. ${ }^{127}$

The afforestation programme experienced yet another challenge during the harvesting of the timber. The local NCs controlled the majority of these plantations on behalf of the NRT. However, the local African communities regarded the plantations as communal property in accordance with African custom and viewed them as accessible to all local residents. This caused tensions with colonial authorities as with the NC for Concession. Annoyed by what he termed, "the disheartening lack of cooperation" with Africans in the Chiweshe Reserve, the NC for Concession insisted that:

122. NAZ, S2995, NRT, Trustees Report, 1946.

123. NAZ, S2990/4, NRT, NC Inyanga to CNC, 23 December 1940.

124. NAZ, S2217/2, NRT, Forest Officers' Reports, Report No. 62, 1940.

125. NAZ, S2217/2, NRT, Forest Officers' Reports, Annual Report, 1940.

126. Davis, "Afforestation in the Mazowe Valley", p 126.

127. A.A. Pardy, quoted in Davis, "Afforestation in the Mazowe Valley", p 126. 
... the people of Chiweshe need some severe lessons on responsibility towards posterity and the near future ... Their attitude is that when hard times come, someone else will provide, and it came as a shock when I would not allow any more cutting in existing plantations because they have got into such a mess. ${ }^{128}$

This, indeed, was a source of contention. The Chiweshe community was convinced that it had the right to cut timber without paying because it had invested its labour, time and tools towards the establishment and maintenance of the plantations. Africans saw the plots as communal property, yet colonial authorities held an opposite view. This failure should be understood from the perspective that indirectly, and symbolically at least, the trees took their place among instruments of colonial domination. ${ }^{129}$ Afforestation in the centralised areas, and forest plots in the reserves, marked out the countryside and served as a reminder to the rural communities of the control the colonial power exercised over the lands where they lived.

\section{Conclusion}

Covering the period from 1924-1948, this article explores aspects of the exploitation of natural resources in African reserves. We note that resource exploitation in African areas during the period under study replicated larger colonial policy that favoured settlers at the expense of Africans. We emphasise that Africans were not passive victims of their situation and that they responded in various ways ranging from cooperating with state officials to contesting state policy. In supporting these points, we examine the centrality of the NRT in controlling resources in African reserves. The NRT, which came into existence in 1924, acted as a product of the gradual shift in the paternalistic "native policy" in Southern Rhodesia, with an emphasis on the ideology of trusteeship. In other words, European authorities acted as "father figures" in the way they related to Africans. ${ }^{130}$ As a trustee of Africans, the NRT inspected both the exploitation of resources and development of African reserves in Southern Rhodesia.

Using archival material from the NRT, the article demonstrates the contestations on the exploitation of timber resources in African reserves between the state, white logging companies and Africans. It also highlights the efforts by the state, through the NRT in tandem with the NAD, to augment the fast-depleting timber resources in African areas. In doing so, the article shows how the NRT became an avenue through which white settler capital penetrated and exploited timber in African reserves; a clear replication of colonial racial policy favouring the welfare of the white settler community at the expense of the Africans. As the NC of Umtali put it, "The trees do not belong to Chief Maranke but to the Natives Reserves Trust". ${ }^{131}$

128. NAZ, S2990/4 NC Concession, Report to the Trust on Grants, 1945/6.

129. Ndione, De Leener, Ndiaye, Jacolin, and Perier, The Future of Community Land, p 48.

130. See for example Hodge and Hodl, "Introduction"; and Steele, "The Foundations of Native Policy: Southern Rhodesia".

131. NAZ, S235/358/360, from NC Umtali to Higgins and Hatcher, 11 February 1928 
The article endorses earlier findings on colonial statecraft and environmental concerns. ${ }^{132}$ Colonial authorities raised concerns about environmental degradation, leading to the promulgation of a number of environmental protection regulations by the 1930s, but rural deforestation continued because laws were less rigidly applied to white companies in the face of the high demand for timber to support railway and mining enterprises. The decade after the Great Depression in 1929 worsened the situation as white settlers increasingly resorted to the exploitation of environmental resources. Indeed, the findings here validate earlier research on the self-serving nature of the Southern Rhodesian state. Faced with the economic challenges of the 1930s, the state cushioned white wood-traders from the worst effects of the Great Depression by supporting white vendors at the expense of African vendors. Other scholars, notably Phimister and Keyter, have shown similar trends in the promulgation of the Cattle and Maize Control Acts during the same period.

Furthermore, this study illuminates a salient irony about the colonial exploitation of timber resources in African reserves. The NRT earned revenue from the various timber logging companies operating in the Africa reserves and yet, by the 1930s, it had to sponsor dozens of afforestation activities in certain reserves that had been affected by deforestation. Even where rural afforestation schemes succeeded, this was not purely a result of the state addressing environmental concerns, but was also designed to increase the carrying capacity of the African reserves and accommodate more Africans who were due for eviction from so-called European lands following the implementation of the Land Apportionment Act from 1931.

\section{REFERENCES}

Alexander, J., McGregor, J. and Ranger, T., Violence and Memory: One Hundred Years in the "Dark Forests" of Matabeleland (Weaver Press, Harare, 2000).

Brown, K., “Trees, Forests and Communities': Some Historiographical Approaches to Environmental History of Africa", Area, 35, 4 (2003).

Davis, A.G., "Afforestation in the Mazowe Valley", Zambezia, 15, 2 (1988).

Davis, D.K., Resurrecting the Granary of Rome: Environmental History and French Colonial Expansion in North Africa (Ohio University Press, Athens: OH, 2007).

Hodge, J. and Hodl, G., "Introduction”, in Hodge, J., Hodl, G and Kopf, M. (eds), Developing Africa: Concepts and Practices in Twentieth-century Colonialism (Manchester University Press, Manchester, 2014).

Jacobs, N.J., Environment, Power and Injustice: A South African History (Cambridge University Press, New York, 2003).

Keyter, C.F., "Maize Control Act in Southern Rhodesia 1931 to 1940: African Contribution to White Survival", Rhodesia History, 8 (1977).

Kwashirai, V., "Poverty in the Gwai Forest Reserve, Zimbabwe: 1880-1953", Global Environment, 1, 1 (2008).

132. Moore and Vaughan, Cutting down Trees. See also Phimister, Economic and Social History of Zimbabwe, pp 184-185; and Keyter, "Maize Control Act in Southern Rhodesia 1931 to $1940 "$. 
Kwashirai, V., "Dilemmas in Conservationism in Colonial Zimbabwe, 1890-1930", Conservation and Society 4, 4 (2006).

Mabulala, C., "The Native Affairs Department in Melsetter District: The Administration of L.C. Meredith, 1895-1909 and P. Nielson, 1926-1936", BA Honours, University of Zimbabwe, 1995).

Madimu, T., Msindo, E. and Swart, S., "Farmer-Miner Contestations and the British South Africa Company in Colonial Zimbabwe, 1895-1923", Journal of Southern African Studies, 44, 5 (2018).

Makombe, E.K., "Developing Rural Africa: Rural Development Discourse in Colonial Zimbabwe, 1944-1971", in Hodge, J, Hodl, G. and Kopf, M. (eds), Developing Africa: Concepts and Practices in Twentieth-century Colonialism, (Manchester University Pres, Manchester, 2014).

Mapedza, E., "Forestry Policy in Colonial and Postcolonial Zimbabwe: Continuity and Change", Journal of Historical Geography, 33 (2007).

Masakure, C., "An Unfulfilled Step: An Examination of the Commission to Investigate the Socio-Economic Conditions of Africans Employed in Urban Areas, 1944", B.A. Honours, Economic History, University of Zimbabwe, May 2001).

Masakure, C., "The Native Reserves Trust Fund and Rural Development in African Areas c 1924-1948", MA thesis, University of Zimbabwe, 2004.

McGregor, J., "Conservation, Control and Ecological Change: The Politics and Ecology of Colonial Conservation in Shurugwi, Zimbabwe", Environment and History, 1, 3 (1998).

Moore, H.L. and Vaughan, M., Cutting Down Trees: Gender, Nutrition and Agricultural Change in the Northern Province of Zambia, 1890-1990 (Heinemann, Portsmouth: $\mathrm{NH}, 1994)$.

Moyana, H., The Political Economy of Land in Zimbabwe (Mambo Press, Gweru, 1984). Mulwafu, W.O., Conservation Song: A History of Peasant-State Relations and the Environment in Malawi, 1860-2000 (White Horse Press, Cambridge, 2011).

Musemwa, M., "Contestations over Resources: Farmer-Miner Disputes in Colonial Zimbabwe, 1903-1939", Environment and History, 15, 1 (2009).

Musemwa, M., “'Sic Utere tuo ut Alienam Non Laedas': From Wanton Destruction of Timber Forests to Environmentalism. The Rise of Colonial Environmental and 'Sustainability' Practices in Colonial Zimbabwe, 1938-1961", Environment and History, 22, 4 (2016).

Ndione, E., De Leener., P., Ndiaye, M., Jacolin, P., and Perier, J., The Future of Community Lands: Human Resources (London, Intermediate Technology, 1995).

Ndumeya, N., "Acquisition, Ownership and Use of Natural Resources in South Eastern Zimbabwe, 1929-1969", PhD thesis, University of the Free State, 2015.

Ndumeya, N., "Conserving Wildlife Resources in Zimbabwe: Reflections on Chirinda Forest, 1920s to 1979", Environment and History, 26, 3 (2020).

Ndumeya, N., "Nature, Conservation and Conflict in Eastern Zimbabwe: The Case of Chirinda Forest, 1980-2000", Journal of Southern African Studies, 45, 2 (2019).

Palmer, R., "Agricultural History of Rhodesia", in Palmer, R., and Parsons, N. (eds), The Roots of Rural Poverty in Central and Southern Africa (University of California Press, Berkeley and Los Angeles, 1977).

Palmer, R., Land and Racial Domination in Rhodesia (Heinemann, London, 1977). 
Passmore, G.C., The National Policy of Community Development with Special Reference to Local Government in the African Rural Areas (University of Rhodesia, Salisbury, 1972).

Phimister, I., "Discourse and the Discipline of Historical Context: Conservationism and Ideas about Development in Southern Rhodesia 1930-1950", Journal of Southern African Studies, 12, 2 (1986).

Phimister, I., An Economic and Social History of Zimbabwe: Capital Accumulation and Class Struggle, 1890-1948 (Longman, London, 1988).

Punt, E., "The Development of African Agriculture in Southern Rhodesia with Particular Reference to the Interwar Years" MA thesis, University of Natal, 1979.

Showers, K.B., Imperial Gullies: Soil Erosion and Conservation in Lesotho (Ohio University Press, Athens: OH, 2005).

Steele, M.C., "The Foundations of Native Policy: Southern Rhodesia, 1923-1933", PhD thesis, Simon Fraser University, 1972.

Tropp, J., Natures of Colonial Change: Environmental Relations in the Making of Transkei (Ohio University Press, Athens: Ohio, 2006). 